\title{
Marked increase in gastric acid secretory capacity after omeprazole treatment
}

\author{
H L Waldum, J S Arnestad, E Brenna, I Eide, U Syversen, A K Sandvik
}

\begin{abstract}
Background-In contrast with the histamine $_{2}\left(\mathrm{H}_{2}\right)$ blockers, proton pump inhibitors have not been shown to give rebound hypersecretion of acid. Taking into consideration the hyperplasia of the enterochromaffin-like (ECL) cell provoked by hypergastrinaemia secondary to profound acid inhibition and the central role of histamine from ECL cells in the regulation of acid secretion, the lack of any rebound acid hypersecretion after treatment with proton pump inhibitors has been questioned.

Aims-To reassess the effect of treatment with omeprazole on post-treatment acid secretion.

Methods and Patients-Basal and pentagastrin stimulated acid secretion were determined in nine patients with reflux oesophagitis before and 14 days after termination of a 90 day treatment period with the proton pump inhibitor omeprazole (40 mg daily). Basal gastrin values as well as meal stimulated gastrin release were determined before and during omeprazole treatment. Furthermore, biopsy samples from the oxyntic mucosa were taken before and at the end of the treatment period for chemical (histamine and chromogranin $A(\mathrm{CgA})$ ) evaluation of the ECL cell mass.
\end{abstract}

Results-A substantial increase in meal stimulated gastrin release during omeprazole treatment resulted in an increased ECL cell mass. Furthermore, $\mathrm{CgA}$ in serum increased during omeprazole treatment suggesting that serum $\mathrm{CgA}$ may be used as a test to evaluate ECL cell hyperplasia. A significant increase in basal and a marked $(50 \%)$ and significant increase in pentagastrin stimulated acid secretion were found after treatment with omeprazole.

Conclusions-Increased acid secretion after a conventional treatment period with a proton pump inhibitor is probably due to ECL cell hyperplasia and may have negative consequences for acid related diseases.

(Gut 1996; 39: 649-653)

Keywords: acid secretion, acid related diseases, gastrin, hisatmine, proton pump inhibitors.

In humans, gastrin is the main physiological regulator of gastric acid secretion. ${ }^{1}$ In the rat, gastrin stimulates acid secretion by releasing histamine ${ }^{2}$ from the enterochromaffin-like (ECL) cell. $^{3-5}$ Also in humans ${ }^{6}$ and other species the stimulation of acid secretion by gastrin is probably mediated by the stimulation of histamine release from the ECL cell. ${ }^{7}$ Gastrin not only regulates the function but also the growth of the ECL cell, ${ }^{8}$ an effect probably mediated by the same receptor, as the functional and trophic effects show the same concentration dependence in $\operatorname{rat}^{29}$ and man. ${ }^{1{ }^{10}{ }^{11}}$ We have previously shown that in the isolated rat stomach maximal histamine stimulated acid secretion is higher than maximal gastrin stimulated acid secretion. ${ }^{12}$ In vivo, the apparently similar maximal gastrin and histamine stimulated acid secretion may be due to the toxicity of histamine making it impossible to administer histamine in a dose giving maximal gastric acid secretion. ${ }^{13}$ Moreover, we have shown that gastrin stimulated histamine release depends on the ECL cell density or mass. ${ }^{14}$ Furthermore, longterm hypergastrinaemia secondary to profound acid inhibition has been reported to induce an increased capacity to secrete acid in the rat. ${ }^{15}$ In humans, treatment with proton pump inhibitors in conventional doses leads to marked hypergastrinaemia ${ }^{16} 17$ and increased density of argyrophil cells (presumably ECL cells). ${ }^{16}{ }^{17}$ Thus one would expect that treatment with such drugs should induce a rebound acid hypersecretion also in humans. The present study was carried out to examine whether treatment with a proton pump inhibitor in a conventional dose can increase post-treatment acid secretory capacity in humans as such an effect could have a negative influence on acid related diseases. Moreover, we also wanted to explore whether chromogranin A (CgA) could be used to assess the ECL cell mass not only in patients with Zollinger-Ellison syndrome, ${ }^{18}$ but also in patients with hypergastrinaemia secondary to acid inhibition.

\section{Methods}

Patients between 20 and 70 years of age with reflux oesophagitis grade $1-3,{ }^{19}$ were invited to participate in the study, if they had not been taking any proton pump inhibitor during the previous six months or histamine ${ }_{2}\left(\mathrm{H}_{2}\right)$ blockers during the previous two weeks. Patients with malignant disease, liver or kidney diseases, or serious heart disease as well as women of childbearing age were not included. The study was approved by the local ethical committee, and the patients were given written information and gave written consent to participate. The study was conducted in accordance with the Declaration of Helsinki. 
Endoscopy with biopsies

Nine men between 39 and 68 years of age participated. They had had symptoms of gastro-oesophageal reflux disease for 1-20 years. Upper gastrointestinal endoscopy was performed using a gastroscope GIF IT20 (Olympus, Japan) and biopsy specimens were taken from the oxyntic mucosa $(5 \mathrm{~cm}$ oral to the angulus from the anterior and posterior wall), using biopsy forceps FB-13K E (Olympus, Japan). The examination was performed after an overnight fast and without premedication or sedation. Two biopsy specimens were frozen directly in liquid nitrogen for later chemical analysis. One of the patients had oesophagitis grade 3, three had grade 2, and five grade $1 .{ }^{19}$

\section{Basal and pentagastrin stimulated acid secretion and meal stimulated gastrin release}

A few days later and after an overnight fast, blood was taken in EDTA tubes for later determination of histamine ${ }^{20}$ and in glass tubes for gastrin and $\mathrm{CgA}$ determination. The patients were then given a test meal consisting of $100 \mathrm{~g}$ beef and $150 \mathrm{ml}$ water taken within 10 minutes, and multiple blood samples were drawn for gastrin determination over a 120 minute period.

Within another few days, basal and maximal acid secretion was determined by a conventional pentagastrin test using pentagastrin (Peptavlon; Zeneca, Cheshire, UK) in a dose of $6 \mu \mathrm{g} / \mathrm{kg}$ body weight subcutaneously as stimulant. Gastric juice was collected for eight 15 minute periods after an initial 30 minute period to empty the stomach. The $\mathrm{H}^{+}$concentration in the gastric juice was determined by titration (Radiometer, Copenhagen, Denmark). Thereafter the patients were given omeprazole (Losec; Astra, Gothenburg, Sweden) $40 \mathrm{mg}$ once daily for 90 days.

During the last treatment week and after an overnight fast, blood sampling and the test meal were repeated as described above. Moreover, the patients underwent a second gastroscopy with biopsy specimens taken from the same area of the stomach and handled as at inclusion. During the first 14 days after the end of the omeprazole treatment, the patients were allowed only antacids for symptomatic relief. Then, after an overnight fast, a new pentagastrin test was caried out as described above.
Blood tests

Gastrin in serum was determined by a commercial radioimmunoassay (RIA) method (Becton Dickinson, Orangeburg, NY, USA). Plasma histamine was also determined by an RIA method (Immunotech, Marseilles, France).$^{5}{ }^{21}$ Antibody to Helicobacter pylori was assessed by an enzyme linked immunosorbent assay (ELISA) as previously described. ${ }^{22} \mathrm{CgA}$ was determined in serum by a commercial ELISA method (Dako, Denmark) as previously used in our laboratory. ${ }^{23}$ The serum/plasma samples were stored at $-20^{\circ} \mathrm{C}$ until analysis.

\section{Assay of histamine and $\mathrm{Cg} A$ in the oxyntic mucosa}

Biopsy samples taken from the oxyntic mucosa and stored in liquid nitrogen were weighed, dissolved in phosphate buffer at a concentration of $100 \mathrm{mg}$ tissue $/ \mathrm{ml}$, and homogenised using a rotating knife homogeniser. ${ }^{15}$ Histamine was determined in the homogenate (after 10 minutes of boiling) by the commercial RIA method used for determination of plasma histamine, and $\mathrm{CgA}$ was determined by a commercial ELISA method (Dako, Denmark). ${ }^{23}$ The blood tests as well as the biopsy specimens were examined blindly.

\section{Statistics}

Wilcoxon's paired signed rank test was used to evaluate statistically the differences induced by the treatment, and Mann-Whitney test to evaluate the differences in gastrin values between $H$ pylori positive and negative patients.

\section{Results}

The oesophagitis was healed in all patients. Three of the patients were positive for $H$ pylori as assessed by serology (Table I).

\section{Plasma gastrin}

Basal plasma gastrin increased in all subjects although in some only marginally. On the other hand, basal plasma gastrin increased more than eightfold in one subject and threefold in two others (Table I). Basal gastrin before treatment was significantly $(p=0.0238)$ higher in the three patients with $H$ pylori infection compared

TABLE I Effect of three months' treatment with omeprazole $40 \mathrm{mg}$ daily on blood basal CgA, gastrin, and histamine, and meal stimulated gastrin release in patients with reflux oesophagitis

\begin{tabular}{|c|c|c|c|c|c|c|c|c|c|c|}
\hline \multirow[t]{2}{*}{ Patient } & \multicolumn{2}{|c|}{$\begin{array}{l}\text { Basal gastrin } \\
\text { (pmoln) }\end{array}$} & \multicolumn{2}{|c|}{$\begin{array}{l}\text { Meal stimulated gastrin } \\
\text { release (area under curve) } \\
\text { (pmol/min } / \text { ) }\end{array}$} & \multicolumn{2}{|c|}{$\begin{array}{l}\text { Peak meal stimulated } \\
\text { gastrin concentration } \\
\text { (pmoll) }\end{array}$} & \multicolumn{2}{|c|}{$\begin{array}{l}\text { Plasma histamine } \\
\text { (nmoll) }\end{array}$} & \multicolumn{2}{|c|}{$\begin{array}{l}\text { Serum } C g A \\
(U I I)\end{array}$} \\
\hline & Before & During & Before & During & Before & During & Before & During & Before & During \\
\hline $\begin{array}{l}1 \\
2 \\
3^{\star} \\
4 \\
5 \\
6^{\star} \\
7 \\
8^{\star} \\
9 \\
\text { Median }\end{array}$ & $\begin{array}{l}14 \\
13 \\
23 \\
12 \\
12 \\
23 \\
12 \\
22 \\
17 \\
14\end{array}$ & $\begin{array}{r}15 \\
18 \\
75 \\
101 \\
17 \\
37 \\
27 \\
64 \\
19 \\
27\end{array}$ & $\begin{array}{l}- \\
1963 \\
5060 \\
2148 \\
1453 \\
3660 \\
1800 \\
2785 \\
1678 \\
2056\end{array}$ & $\begin{array}{r}2232 \\
7628 \\
17095 \\
9908 \\
4345 \\
16893 \\
8165 \\
13240 \\
7783 \\
8165\end{array}$ & $\begin{array}{l}20 \\
69 \\
24 \\
13 \\
47 \\
20 \\
28 \\
20 \\
20\end{array}$ & $\begin{array}{r}25 \\
86 \\
176 \\
104 \\
42 \\
172 \\
93 \\
122 \\
91 \\
91\end{array}$ & $\begin{array}{l}3 \cdot 3 \\
2 \cdot 9 \\
3 \cdot 6 \\
3 \cdot 3 \\
2 \cdot 6 \\
2 \cdot 6 \\
7 \cdot 4 \\
3 \cdot 6 \\
5 \cdot 9 \\
3.9\end{array}$ & $\begin{array}{l}4 \cdot 0 \\
5 \cdot 1 \\
2 \cdot 6 \\
4 \cdot 2 \\
3 \cdot 6 \\
3 \cdot 0 \\
4 \cdot 2 \\
4 \cdot 2 \\
4 \cdot 6 \\
4 \cdot 2\end{array}$ & $\begin{array}{r}9 \cdot 2 \\
9 \cdot 1 \\
5 \cdot 4 \\
12 \cdot 0 \\
11 \cdot 0 \\
23 \cdot 0 \\
10 \cdot 0 \\
22 \cdot 0 \\
5 \cdot 4 \\
10 \cdot 0\end{array}$ & $\begin{array}{r}24 \cdot 0 \\
9 \cdot 1 \\
24 \cdot 0 \\
34 \cdot 0 \\
16 \cdot 0 \\
55 \cdot 0 \\
13 \cdot 0 \\
74 \cdot 0 \\
13 \cdot 0 \\
24 \cdot 0\end{array}$ \\
\hline
\end{tabular}

${ }^{\star}$ Helicobacter pylori positive. 
with the other six $H$ pylori negative patients. Although plasma gastrin only increased marginally in most of the patients, the integrated two hour gastrin response to the test meal increased substantially in all subjects (Table I). The increase in meal stimulated gastrin release after omeprazole treatment depended on the meal stimulated release before treatment and increased threefold to fourfold compared with that before the treatment period (Table I). Moreover, integrated meal stimulated gastrin release before $(p=0.0357)$ as well as during $(p=0.0238)$ omeprazole treatment was significantly increased in patients with $H$ pylori infection.

\section{Plasma histamine and $C g A$ in serum}

Plasma histamine did not increase significantly during the omeprazole treatment period (Table I). On the other hand, serum CgA increased in eight of the patients and was unchanged in the ninth $(p=0.002)$ (Table I).

\section{Gastric acid secretion}

Basal acid secretion increased significantly after omeprazole treatment $(p<0.05)$. In one of the subjects, it became as high as $16 \mathrm{mmol} / \mathrm{h}$ (Figure).

Pentagastrin stimulated acid secretion increased in seven and was unchanged in one of the eight subjects studied (Figure) $(p=0.004)$. In one patient (patient 3 ) the acid secretion could not be assessed owing to heavy duodenogastric reflux (dark brown bilirubin stained gastric juice) on both occasions. Pentagastrin stimulated acid secretion was nearly doubled in patients 5 and 6 , and a substantial increase was noted in all but two patients (patients 2 and 8 ). Median pentagastrin stimulated acid secretion increased $50 \%$ (from 27.9 to $42.4 \mathrm{mmol} / \mathrm{h}$ ).
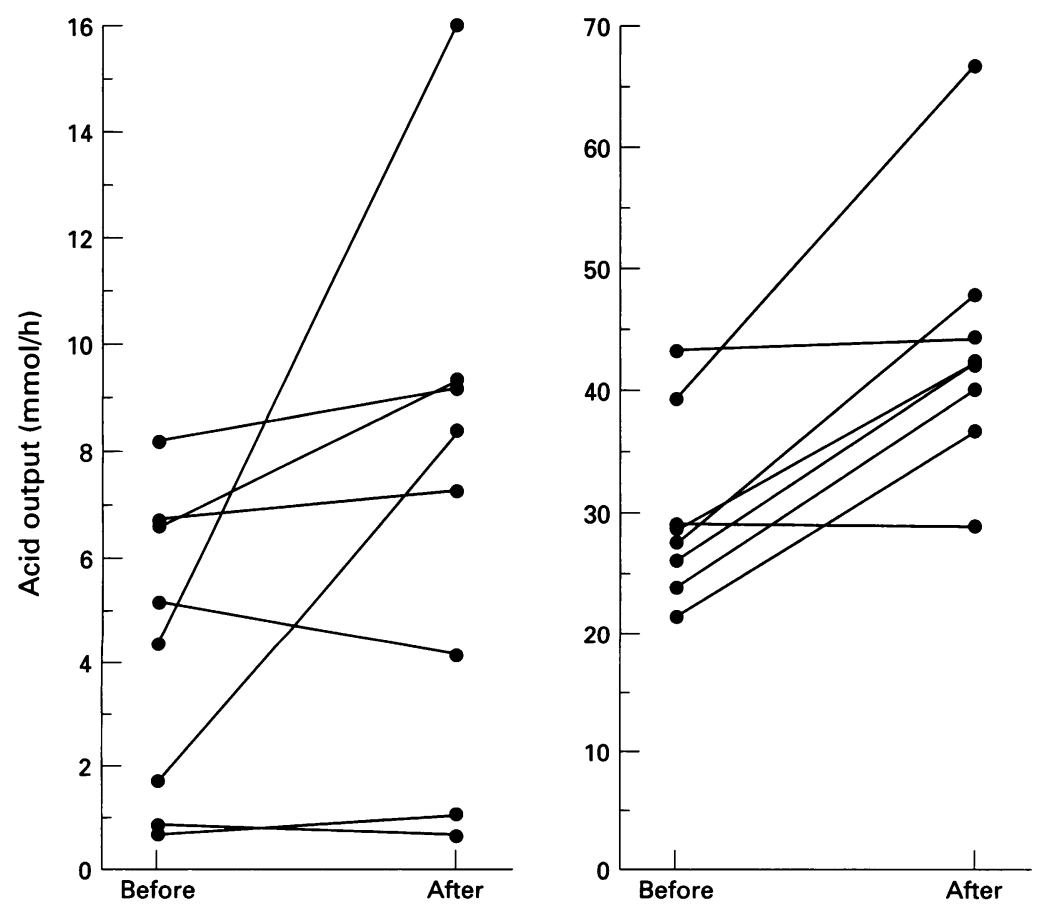

Basal (left) and pentagastrin stimulated (right) acid secretion before and 14 days after a 90 day treatment period with omeprazole $40 \mathrm{mg}$ daily.
Histamine and $C g A$ in the oxyntic mucosa

Histamine increased significantly $(\mathrm{p}=0.02)$ in the oxyntic mucosa over the omeprazole treatment period (Table II). The increase in CgA was even more marked and highly significant $(p=0.004)$ (Table II).

\section{Discussion}

For the first time a marked gastric acid hypersecretion after treatment with a proton pump inhibitor has been found in humans. This is in agreement with a previous study in rats where gastric acid hypersecretion was recorded one week after the end of longterm treatment with omeprazole. ${ }^{1524}$ The acid hypersecretion in these rats persisted for at least 70 days. ${ }^{15} 24$ Previously, tolerance to $\mathrm{H}_{2}$ blockers has been described whereas no such tolerance has been reported after treatment with proton pump inhibitors. ${ }^{25}$ Rebound acid hypersecretion has been recorded after even a relatively short treatment period of four weeks with an $\mathrm{H}_{2}$ receptor antagonist. ${ }^{26}$ The dose of omeprazole used in the present study ( $40 \mathrm{mg}$ daily) is higher than that reported to give maximal inhibition of acid secretion in patients with duodenal ulcer by Sharma et $a l^{27}$ but lower than the dose giving maximal inhibition of pentagastrin stimulated acid secretion in healthy volunteers. ${ }^{28}$ Nevertheless, the dose used probably gave a profound inhibition of acid secretion in these patients, which is supported by the increased basal and meal stimulated gastrin release. Acid secretion as assessed by the $\mathrm{pH}$ in aspirated aliquots of gastric juice in healthy volunteers after a three week treatment period with either ranitidine $300 \mathrm{mg}$ or omeprazole $40 \mathrm{mg}$ per day has previously been studied up to 21 days after cessation of treatment without any change in nocturnal acidity. ${ }^{29}$ The apparent discrepancy between that study and the present one is probably because the treatment period in the study of Prewett and coworkers was too short. ${ }^{29}$ In fact, the ECL cell density as assessed by argyrophil cell density increased markedly from day 30 to day 60 of hypergastrinaemia in rats. ${ }^{30}$ In agreement with previous studies, ${ }^{31}$ fasting gastrin and meal stimulated gastrin release were higher in patients with $H$ pylori infection. One of the patients with $H$ pylori infection had marked duodenogastric reflux with bile stained gastric juice. Although

TABLE II Effect of three months' treatment with omeprazole $40 \mathrm{mg}$ daily on the concentration of histamine and $C g A$ in the oxyntic mucosa

\begin{tabular}{lcclll}
\hline \multirow{2}{*}{ Patient } & \multicolumn{2}{l}{ Histamine $($ nmollg) } & & \multicolumn{2}{l}{$C g A(U / g)$} \\
\cline { 2 - 3 } \cline { 5 - 6 } & Before & During & & Before & During \\
\hline 1 & 96 & 55 & & $0 \cdot 84$ & $0 \cdot 72$ \\
2 & 82 & 91 & & $1 \cdot 45$ & $3 \cdot 80$ \\
$3^{\star}$ & 62 & 255 & & $0 \cdot 27$ & $3 \cdot 10$ \\
4 & 131 & 161 & & $2 \cdot 90$ & $6 \cdot 00$ \\
5 & 107 & 101 & & $2 \cdot 35$ & $3 \cdot 30$ \\
$6^{\star}$ & 91 & 184 & & $0 \cdot 96$ & $4 \cdot 00$ \\
7 & 61 & 120 & & $1 \cdot 30$ & $4 \cdot 30$ \\
$8^{\star}$ & 51 & 130 & & $0 \cdot 65$ & $5 \cdot 00$ \\
9 & 64 & 127 & & $0 \cdot 84$ & $2 \cdot 90$ \\
Median & 82 & 127 & $0 \cdot 96$ & $3 \cdot 80$ \\
\hline
\end{tabular}

${ }^{\star}$ Helicobacter pylori positive. 
duodenogastric reflux is usually quite small, not affecting the clinical value of the gastric acid secretory test, it may vary from 0.1 to $22.3 \%$ in healthy volunteers. ${ }^{32}$ Naturally, duodenograstric reflux makes basal gastric acid secretion less reliable than stimulated values. In the present study basal gastric juice in patient 3 was not only bile stained, but also alkaline. Therefore, it was quite clear that the secretory data from this patient could not be used in the assessment of rebound acid hypersecretion in this study. Ideally, this patient should have been removed from the study at the initial phase because of the observed duodenogastric reflux. However, exclusion of this patient would have meant that only two patients with $H$ pylori infection would have had pre- and post-treatment acid secretion determined. In one of these patients (patient 8 ) both basal and pentagastrin stimulated acid secretion were unaffected by the treatment with omeprazole whereas it increased markedly in the other patient (patient 6) with $H$ pylori infection (pentagastrin stimulated acid secretion increased from $27 \cdot 3$ to $47.8 \mu \mathrm{mol} / \mathrm{h}$ ).

The effect of omeprazole persists for at least one week. ${ }^{27}$ Therefore, it is mandatory to wait for longer than this to be able to detect rebound acid hypersecretion. In the present study we determined acid secretion two weeks after the end of treatment with the proton pump inhibitor and detected an increased pentagastrin stimulated as well as basal acid secretion. In vivo 24 hour gastric acidity reflects basal as well as food stimulated acid secretion. Since gastrin is the dominating secretagogue for meal stimulated acid secretion, ${ }^{1}$ the described increase in pentagastrin stimulated acid secretion would be expected to lead to an augmented food stimulated acid secretion. Furthermore, as longterm inhibition of acid secretion also leads to an increase in antral $G$ cells and decrease in somatostatin (D) cells, ${ }^{30}$ food stimulated acid secretion after long-term treatment with potent inhibitors of acid secretion could lead to an even more marked acid hypersecretion than detected by pentagastrin stimulated acid secretion. It is possible that GRP stimulated acid secretion ${ }^{33}$ could be an even more sensitive test for post-treatment acid hypersecretion. The clinical impact of this post-treatment acid hypersecretion remains to be shown. However, gastric acid plays a pathogenetic part in both peptic ulcer disease and reflux oesophagitis. Therefore, it is conceivable that the demonstrated acid hypersecretion may have a negative effect and contribute to the recurrence of both these diseases. The hypergastrinaemia secondary to the inhibition of acid secretion by omeprazole probably induced the post-treatment gastric acid hypersecretion. Basal gastrin increased in all subjects during treatment. The increase in basal gastrin was, however, slight or moderate with a value above $100 \mathrm{pmol} / \mathrm{l}$ in only one patient. However, even moderate hypergastrinaemia has a significant trophic effect on the ECL cell. ${ }^{9}$

Furthermore, as shown in this study, basal gastrin values during treatment with proton pump inhibitors underestimate the postprandial hypergastrinaemia, which was greatly increased in all subjects during omeprazole treatment. Thus, the 24 hour gastrin stimulation is considerably raised in patients treated with proton pump inhibitors. Taking into consideration that the maximal trophic effect of gastrin on the ECL cell is reached at a lower concentration than previously thought in humans, ${ }^{10}$ as in the rat, ${ }^{9}$ it is probable that near maximal stimulation of ECL cell growth was obtained during a greater part of the day in some of the patients, for instance patients 3 and 6 , who both had postprandial gastrin values just above $170 \mathrm{pmol} / \mathrm{l}$ (Table I).

It is now established that the ECL cell plays a central part in the regulation of gastric acid secretion. ${ }^{7}$ Furthermore, it is probable that gastrin induced histamine release is the limiting factor for gastric acid secretion after gastrin stimulation as well as meal stimulated acid secretion..$^{34}$ We found an increased histamine concentration in the oxyntic mucosa after omeprazole treatment, which probably reflects an increase in the ECL cell mass, especially as it was accompanied by a similar increase in CgA. An increased ECL cell density in the oxyntic mucosa in humans is well known after omeprazole treatment. ${ }^{16}$ Lamberts et al reported a doubling of the density of argyrophil cells in the oxyntic mucosa in patients with peptic ulcer treated with omeprazole for one to two years at the dose of $40 \mathrm{mg}$ daily. ${ }^{16}$ Taking into consideration that the ECL cell, the only argyrophilic cell in the oxyntic mucosa where gastrin has a positive trophic effect, ${ }^{35}$ normally represents only $35 \%$ of these cells, ${ }^{36}$ a doubling of the density of the argyrophilic cells probably indicates an even more marked increase in the ECL cell density than just a doubling. Furthermore, gastrin has a negative trophic effect on the $\mathrm{D}$ cell in the oxyntic mucosa. ${ }^{37}$ Accordingly, the described increase in argyrophilic cell density represents a massive increase in the ECL cell mass and function in the oxyntic mucosa. On the other hand, proton pump inhibitor treatment seems not to induce an increase in parietal cell density. ${ }^{15}$

Longterm hypergastrinaemia in humans is accompanied by gastric acid hypersecretion. ${ }^{38}$ This gastric acid hypersecretion may be controlled by treatment with proton pump inhibitors in normal doses, ${ }^{39}$ whereas $\mathrm{H}_{2}$ blockers have to be used in greatly increased doses, ${ }^{40}$ suggesting an increase in the histamine concentration in the oxyntic mucosa. ${ }^{34}$ Altogether, the findings of this study and previous studies $^{16}{ }^{34-40}$ suggest that increased histamine due to ECL cell hyperplasia is the most important mechanism for increased acid secretory capacity after prolonged hypergastrinaemia. Furthermore, this study shows that $\mathrm{CgA}$ in blood may be used to assess the neuroendocrine cell mass in the stomach whereas plasma histamine cannot be used to estimate the ECL cell mass (Table I). Contamination of histamine released from granulocytes at the blood sampling and preparation of plasma $^{20}$ is probably the main reason for the lack of correlation between plasma histamine 
on one hand and serum CgA or ECL cell mass on the other.

In conclusion, this study shows for the first time that treatment with a proton pump inhibitor in a conventional dose even in humans induces post-treatment gastric acid hypersecretion, which may have negative influences on the diseases for which they were prescribed. Furthermore, this increase in acid secretion is probably due to an increased ECL cell mass secondary to hypergastrinaemia during the treatment period.

1 Blair AJ, Richardson CT, Walsh JN, Feldman M. Variable contribution of gastrin to gastric acid secretion after a meal in humans. Gastroenterology 1987; 92: 944-9.

2 SandvikAK, Waldum HL, Kleveland PM, Schulze Søgnen B. Gastrin produces an immediate and dose-dependent histamine release preceding acid secretion in the totally isolated, vascularly perfused rat stomach. Scand $\mathscr{f}$ Gastroenterol 1987; 22: 803-8.

3 Brenna E, Waldum HL. Studies of isolated parietal and enterochromaffin-like cells from the rat. Scand $f$ Gastroenterol 1991; 26: 1295-306.

4 Prinz C, Kajimura M, Scott DR, Mercier F, Helander HF, Sachs G. Histamine secretion from rat enterochromaffinlike cells. Gastroenterology 1993; 105: 459-61.

5 Waldum HL, Sandvik AK, Brenna E, Schulze Søgnen B. Radioimmunoassay of histamine. Scand $\mathcal{f}$ Gastroenter 1991; 26 (suppl 180): 32-9.

6 Leth R, Olbe L, Haglund U. The pentagastrin-induced gastric acid response in humans. Scand $f$ Gastroenterol 1988; 23: 224-48.

7 Waldum HL, Sandvik AK, Brenna E, Petersen H. Gastrin histamine sequence in the regulation of gastric acid secretion Gut 1991; 32:698-701.

8 Ryberg B, Tielemans Y, Axelson J, Carlsson E, Håkanson R Mattson $\mathrm{H}$, et al. Gastrin stimulates the selfreplication rate of enterochromaffin-like cells in the rat stomach. Gastroenterology 1990; 99: 935-42.

9 Brenna E, Waldum HL. Trophic effect of gastrin on the enterochromaffin like cells of the rat stomach: establishment of a dose response relationship. Gut 1992; 33. 1303-6.

10 Sjöblom S-M, Sipponen P, Karonen S-L, Järvinen HJ Argyrophil cell hyperplasia and carcinoid tumours in oxyntic mucosa of the stomach. Dependence on duration ox pernicious anaemia. Eur $\mathcal{f}$ Gastroenterol Hepatol 1991; of pernicious

11 Waldum HL, Sandvik AK, Syversen U, Brenna E. The enterochromaffin-like (ECL) cell. Physiological and pathophysiological role. Acta Oncol 1993; 32: 141-7.

12 Kleveland PM, Waldum HL, Larsson H. Gastric acid secretion in the totally isolated, vascularly perfused rat stomach. A selective muscarinic-1 agent does, whereas gastrin does not, augment maximal histamine-stimulated acid secretion. Scand 7 Gastroenterol 1987; 22: 705-13.

13 Waldum HL, Sandvik AK. Histamine and the stomach. Scand $\mathcal{F}$ Gastroenterol 1989; 24: 130-9.

14 Waldum HL, Lehy T, Brenna E, Sandvik AK, Petersen H, Schulze Søgnen B, et al. Effect of the histamine-1 antagonist astemizole alone or with omeprazole on rat antagonist astemizole alone or with omeprazole on

15 Larsson H, Carlsson E, Ryberg B, Fryklund J, Wallmark B Rat parietal cell function after prolonged inhibition of gastric acid secretion. Am $\mathcal{Y}$ Physiol 1988; 254: G33-9.

16 Lamberts R, Creutzfeldt W, Stöckmann F, Jacubaschke U, Maas S, Brunner G. Long-term omeprazole treatment in man: effects on gastric endocrine cell populations. Digestion 1988; 39: 126-35.

17 Klinkenberg-Knol EC, Festen HPM, Jansen JBMJ, Lamers CBHW, Nelis F, Snel P, et al. Long-term treatment with omeprazole for refractory reflux oesophagitis: efficacy and safety. Ann Intern Med 1994; 121: 161-7.

18 Syversen U, Mignon M, Bonfils S, Kristensen A, Waldum HL Chromogranin $A$ and pancreastatin-like immunoreactivity in serum of gastrinoma patients. Acta Oncol 1993; 32: 161-5.
19 Savary M, Miller G. The oesophagus. Solothurn: Gassmann, 1977.

20 Lorenz W. Histamine release in man. Agents Actions 1975 5: 402-16.

21 Morel AM, Delaage MA. Immunoanalysis of histamine through a novel chemical derivatization. f Allergy Clin Immunol 1988; 82: 646-54.

22 Maeland JA, Kleveland PM, Neass AI. Contribution of antibodies reacting with Campylobacter jejuni antigens in the testing of human sera for anti-Helicobacter pylori antibodies. Serodiagnosis and immunotherapy in infectious disease 1993; 1: 32-6.

23 Syversen U, Jacobsen MB, O'Connor DT, Rønning K, Waldum HL. Immunoassays for measurement of chromogranin A and pancreastatin-like immunoreactivity in humans: correspondence in patients with neuroendocrin neoplasia. Neuropeptides 1994; 26: 201-6.

24 Carlsson E, Larsson H, Mattsson H, Ryberg B, Sundell G Pharmacology and toxicology of omeprazole with special reference to the effects on the gastric mucosa. Scand $\mathcal{F}$ Gastroenterol 1986; 21 (suppl 18): 31-8.

25 Merki HS, Wilder-Smith CH. Do continuous infusions of omeprazole and ranitidine retain their effect with prolonged dosing? Gastroenterology 1994; 106: 60-4.

26 Fullarton GM, McLauchlan G, MacDonald A, Crean GP McColl KEL. Rebound nocturnal hypersecretion after McColl KEL. Rebound nocturnal hypersecretion after four weeks treatment

27 Sharma BK, Walt RP, Pounder RE, Gomes $M$ de FA Wood EC, Logan LH. Optimal dose of oral omeprazole for maximal 24 hour decrease of intragastric acidity. Gut 1984; 25: 957-64.

28 Lind T, Cederberg C, Ekenved G, Haglund U, Olbe L. Effect of omeprazole - a gastric proton pump inhibitor on pentagastrin stimulated acid secretion in man. Gut 1983; 24: 270-6.

29 Prewett EJ, Hudson M, Nwokolo CU, Sawyerr AM, Pounder RE. Nocturnal intragastric acidity during and after a period of dosing with either ranitidine or omeprazole. Gastroenterology 1991; 100: 873-7.

30 Creutzfeldt W, Stöckmann F, Conlon JM, Fölsch UR, Bonatz $G$, Wülfrath $M$. Effect of short- and long-term feeding of omeprazole on rat gastric endocrine cells. Digestion 1986; 35 (suppl 1): 84-97.

31 Prewett EJ, Smith JTL, Nwokolo CU, Hudson M, Sawyer AM, Pounder RE. Eradication of Helicobacter pylori abolishes 24-hour hypergastrinemia: a prospective study in healthy subjects. Aliment Pharmacol Ther 1991; 5: $283-90$.

32 Go VLW, Hofmann AF, Summerskill WHJ. Simultaneous measurements of total pancreatic, biliary, and gastric outputs in man using a perfusion technique. Gastroenterology 1970; 58: 321-8.

33 El-Omar E Penman I, Dorrian CA Ardill JES McColl KEL. Eradicating Helicobacter pylori infection lowers gastrin mediated acid secretion by two thirds in patients with duodenal ulcer. Gut 1993; 34: 1060-5.

34 Waldum HL, Brenna E, Kleveland PM, Sandvik AK. Gastrin - physiological and pathophysiological role clinical consequences. Dig Dis 1995; 13: 25-38.

35 Tielemans Y, Axelson J, Sundler F, Willems G, Håkanson R. Serum gastrin concentration affects the self-replication rate of the enterochromaffin like cells in the rat stomach. Gut 1990; 31: 274-8.

36 Sundler F, Håkanson R. Gastric endocrine cell typing at the light microscopic level. In: Håkanson R, Sundler F, eds. The stomach as an endocrine organ. Erik Fernstrøm Symposium. Amsterdam: Elsevier, 1991: 9-26.

37 Chen D, Uribe A, Håkanson R, Sundler F. Somatostatin cells in the oxyntic mucosa of hypo- or hypergastrinemic rats. Scand f Gastroenterol 1992; 27: 479-82.

38 Pisegna JR, Norton JA, Slimack GG, Metz DC, Maton PN, $\mathrm{Gardner} \mathrm{JD}$, et al. Effects of curative gastrinoma resection on gastric secretory function and antisecretory drug requirement in the Zollinger-Ellison syndrome. Gastroenterology 1992; 102: 767-78.

39 Metz DC, Pisegna JR, Fishbeyn VA, Benya RV, Feigenbaum KM, Koviack PD, et al. Currently used doses of omeprazole in Zollinger-Ellison syndrome are too high Gastroenterology 1992;103: 1498-508.

40 Saeed ZA, Norton JN, Frank WO, Young MD, Maton PN, Gardner JD, et al. Parietal antisecretory drug therapy in patients with Zollinger-Ellison syndrome. Gastroenterology 1989; 96: 1396-402. 